\title{
THE SACRED COW OF CORPORATE EXISTENCE PROBLEMS OF DEADLOCK AND DISSOLUTION
}

\author{
Cartos L. Israets*
}

CORPORATION $\ldots$ is a mere conception of the legislative mind. It
exists only on paper through the command of the legislature that
its mental conception shall be clothed with power"- thus, a famous Judge of the New York Court of Appeals in 1912. ${ }^{1}$ Among the powers with which the corporation is thus clothed is the power to survive the death of its owners or any one or more of them. Indeed, under most statutes corporate existence is permitted to be perpetual and the vast majority of certificates filed under those statutes so provide. By the same token destruction of the legislative creature is not easy. Historically the courts have been reluctant to destroy it except under conditions expressly spelled out by the legislature as warranting such action; and even under such conditions the courts are wont to speak of dissolution as a "drastic" remedy and to seek almost any other available alternative before resorting to it.

It is the writer's view that this sacred cow has all too often been an effective road block in cases where the over-all best interests of the owners of the enterprise call for its dissolution or liquidation. Such situations most commonly arise in what we have come to call "close corporations." By that term, we do not necessarily imply that the enterprise is a small one -or that the number of its shareholders is relatively few, although the latter, at least, is usually the case. What we do mean, is a corporation where management and ownership are substantially identical to the extent that the independent judgment of directors is, in fact, a fiction. ${ }^{2} \mathrm{We}$ mean the corporate entity typically organized by an individual, or a group of individuals, seeking the recognized advantages of incorporation, limited liability, perpetual existence and easy transferability of interests-but regarding themselves basically as partners and seeking veto powers as

* Member of the New York Bar.

I Vann, J. in People v. Knapp, 201 N.Y. 373, 381, 99 N.E. 841, 844 (1912).

2 The Validity of Stockholders' Voting Agreements in Illinois, 3 Univ. Chi. L. Rev. 640, 647 (1936). A similar definition was adopted by the New York State Law Revision Commission, N.Y. Leg. Doc. No. 65 K (1948) pp. 389 et seq. 
among themselves much more akin to the partnership relation than to the statutory scheme of representative corporate government. ${ }^{3}$

The first result of the search for veto powers is to circumscribe easy transferability of interests. A partnership status is not assignable but, theoretically, the shareholder in a close corporation can sell his shares, subject, of course, to the impediment that the realization of anything like fair value for them is often stultified by lack of any real market. The members of a partnership have complete personal veto power over the admission of a new partner. The participants in close corporations seek the same result through cross option agreements on their shareholdings. The analogy is not complete because the rule against unreasonable restraints on alienation limits them to the cross option device and thus denies the full and complete veto which the participants each would like to wield. ${ }^{4}$

The individuals seek job security for long and even indefinite periods. They agree to vote annually for each other's election as directors, and contract in advance that, as directors, they will vote to employ themselves in stated capacities and at stated salaries or at salaries bearing consistent relations to each other. With the trend of increasing income taxation and the return of the excess profits tax the tendency has been to make those salaries as high as the traffic will bear or as the Bureau of Internal Revenue will allow in order to minimize the total tax cost of doing business.

Despite the theory that the function of directors is to direct and not merely to carry out the contractual arrangements of those who elected them, the individuals seek personal veto powers over matters which legally are the function of the board. They seek those powers either frankly in those terms or through charter or by-law provisions requiring unanimity or qualified majority action by directors or shareholders or both, carefully safeguarding such provisions against amendment by less than the qualified majority.

No one doubts the ability of partners to agree that certain of their number shall be managing partners, that decisions on matters of business policy shall be taken by the managing partners alone, by all the partners or by a qualified majority. The participants in close corporations merely seek

${ }^{3}$ See generally, Israels, The Close Corporation and the Law, 33 Cornell L.Q. 488 (1948); Delaney, The Corporate Director: Can His Hands Be Tied in Advance, 50 Col. L. Rev. 52 (1950).

${ }^{4}$ See generally 12 Fletcher, Cyclopedia of Corporations (perm. ed., 1931) $\S \S 5453,5456$; Bloomingdale v. Bloomingdale, 107 Misc. 646, 177 N.Y. Supp. 873 (Sup. Ct., 1919); People v. Galskis, 233 Ill. App. 414 (1924); Restrictions on Sale of Corporate Stock, 2 A.L.R. 2d 745 (1948); O'Neal, Restrictions on Transfer of Stock in Closely Held Corporations; Planning and Drafting, 65 Harv. L. Rev. 773 (1952). 
to adapt the corporate form to reach similar results, but when they do the courts of several states have held that such agreements fly in the face of statutes providing that "the business of the corporation shall be managed by its board of directors."

The Courts of New York, New Jersey and Virginia, for example, have struck down shareholder agreements requiring unanimity or qualified majority for directorial action. ${ }^{6} \mathrm{New}$ York relaxes the severity of the rule when the question is one of job security and the individual is on good behavior. ${ }^{7}$

The Illinois Courts showed more flexibility. They by-passed the question of compliance with the statutory scheme, and specifically enforced the agreement of the individuals, though the results were that the board of directors was in fact deprived of some of its theoretical discretion. ${ }^{8}$ With the adoption of the Business Corporation Act in 1933 the situation in Illinois was clarified. By specific provision of that Act charter provisions requiring qualified majority for shareholder action, and by-law provisions requiring it for directors' action are permitted. ${ }^{9}$

Four years ago New York sought to bring itself in line with Illinois. The Court of Appeals had decided four to three that an agreement between a $60 \%$ and a $40 \%$ shareholder of a close corporation that unanimous action should be required by the directors and by shareholders on all issues was unenforcible and void except so far as it forbade amendment of the by-laws by less than unanimous consent. ${ }^{10}$ On the recommendation of the Law Revision Commission the legislature added Section 9 to the Stock Corporation Law. This section specifically permits charter requirements of unanimity or qualified majority for stockholders' or directors' action either in general or on specified issues. II Its provisions have been much availed of.

\footnotetext{
${ }^{5}$ Most of the statutes use this or similar language. See Parker, Corporation Manual (published annually) passim.

- Benintendi v. Kenton Hotel, Inc., 294 N.Y. 112, 60 N.E. 2d 829 (1945); Jackson v. Hooper, 76 N.J. Eq. 592, 75 Atl. 568 (1910); Kaplan v. Block, 183 Va. 327, 31 S.E. 2d 893 (1944). "To ask that directors be divested of all power and that without the consent of every stockholder no one should have power to do anything is to ask too much." Kaplan v. Block, ibid., at $337,897$.

${ }^{7}$ See, e.g., Clark v. Dodge, 269 N.Y. 410, 199 N.E. 641 (1936).

${ }^{8}$ Kantzler v. Bensinger, 214 Ill. 589, 73 N.E. 874 (1905); Fitzgerald v. Christie, 242 Ill. App. 343 (1926). Cf. Specific Enforcement of Shareholder Voting Agreements, 15 Univ. Chi. L. Rev. 738 (1948).

${ }^{9}$ Ill. Bus. Corp. Act (1951) \$§ 37, 146.

${ }^{10}$ Benintendi v. Kenton Hotel, Inc., 294 N.Y. 112, 60 N.E. 2d 829 (1945).

11 N.Y. Stock Corp. Law (McKinney, 1943) § 9 added by N.Y.L. (1948) c. 862, \$1, amended by N.Y.L. (1949) c. 261 and N.Y.L. (1951) c. $717, \S 1$.
} 
Thus the trend has been and will, I think, continue by statute or by decision to permit the participants in close corporations in one way or another to preserve the type of veto powers over the administration of the corporate enterprise which partners commonly contract for. But partnership continues either for a specific agreed period or at will. Thus, time at least provides a remedy if a falling out occurs, and dissolution or winding up or both will break the impasse. On this analogy the New York statute originally provided that charter requirements of unanimity or qualified majority should be valid for a maximum period of ten years, after which they could be renewed for one or more similar periods. However, by amendment in 1951 the limitation was eliminated, and thus we have in most states of the Union the problem of dealing with a set-up originally based on mutual confidence and good will which is no longer present, embodied in what amounts to a contractual arrangement in perpetuity.

If I am right about the trend, we shall have not only more deadlock cases, but more cases of stalemate-the consistent non-cooperation, with or without moral justification, of one or more individuals-which can seriously harm the enterprise and the interests of the majority. The powers of our courts derived from statutes or precedents have, I think, often proven inadequate to deal with the strict deadlock cases largely because the sacred cow of corporate existence blocks the road. A fortiori in the stalemate cases where, unless we carry our legal thinking forward with the trend, we may well find that perpetual existence for some close corporations has turned from an advantage to a detriment.

The courts of many states have held they have no power-absent statute-to dissolve or wind up the affairs of a corporation. The statutory pattern universally permits dissolution at the suit of the state-for nonpayment of taxes or like cause. In most states this is supplemented by provisions for "voluntary" dissolution pursuant to corporate act by the directors ${ }^{12}$ or by shareholder action, sometimes by qualified, e.g., twothirds majority. ${ }^{13}$ In a lesser number of states there are "involuntary" dissolution statutes, permitting suit by the holders of varying percentages of the outstanding shares from fifty percent ${ }^{14}$ down to a single shareholder. ${ }^{15}$ Cases of the type that interest us here arise under the in-

12 Michigan and New York.

13 Parker, Corporation Manual, passim.

14 E.g., Mich. Stat. Ann. (1943) § 27.2354; N.Y. Gen. Corp. Law (McKinney, 1943) § 103, amended by N.Y.L. (1944) c. 176; Ohio Code Ann. (rev. ed., 1948) \$§ 8623-86.

15 IIl. Bus. Corp. Act (1951) §86; Minn. Stat. (1949) $\$ 301.50$. 
voluntary dissolution statutes, many of which are aimed in specific terms at the deadlock situation. ${ }^{16}$

However as one might expect, many of these statutes have been strictly construed. The leading, and much quoted Illinois case of Wheeler v. Pullman Iron \& Steel Co., ${ }^{17}$ first affirms that absent statute the courts have no power to dissolve; then construes the Illinois statute in force at the time, which permitted dissolution only "for good cause shown" as requiring "Iegal cause-a cause for which the sovereign authority might by law, resume the franchise granted."18 Later Illinois decisions held that while an ultra vires act would constitute "good cause"19 the deadlock situation was not covered. ${ }^{20}$

Where the statute is specifically aimed at deadlock the case is not so difficult. But here also, strict construction, consistent with the untouchability of the sacred cow, has been the history. Many of the deadlock provisions are modeled on the New York statute as it stood from 1929 to 1944.

If a corporation has an even number of directors who are equally divided respecting the management of its affairs, the holders of one-half of the stock entitled to vote at an election of directors may present a verified petition for dissolution of the corporation as prescribed in this article. ${ }^{21}$

By its plain terms the statute seems to permit a stockholder petition only if the corporation has a deadlocked board of directors, and such was its construction. Early cases under it dismissed the petition when the certificate or by-laws called for an uneven number of directors. ${ }^{22}$ It took the New York Courts ten years to reach the conclusion that "an even number of directors who are equally divided" is just as effectively created by the resignation or refusal to function of the odd director as by the provisions of the certificate or a by-law. ${ }^{23}$

The courts of other states have not been even so imaginative. New Jer-

${ }^{16}$ There is an excellent analytical and comparative study of the deadlock statutes as they stood in 1944 by the New York Law Revision Commission. N.Y. Leg. Doc. No. 65 K (1944) pp. 348 et seq. For today's texts see Parker, Corporation Manual, passim.

17143 Ill. 197, 32 N.E. 420 (1892).

${ }^{18}$ Ibid., at 207, 422.

${ }^{19}$ Bixler v. Summerfield, 195 Ill. 147, 62 N.E. 849 (1902).

${ }^{20}$ Gidwitz v. Cohen, 238 Ill. App. 227 (1925).

${ }^{21}$ N.Y. Gen. Corp. Law (McKinney, 1943) $\S 103$, as it stood prior to its amendment by N.Y.L. (1944) c. 176, § 2.

22 E.g., In re Fehrenbach, 155 Misc. 663, 281 N.Y. Supp. 149 (1935).

${ }^{23}$ Matter of Binder (Rednib Realty Corp.) 258 App. Div. 1041, 17 N.Y.S. 2d 1020 (1st Dep't, 1939). 
sey requires that the corporation have "an even number of directors who are equally divided respecting the management of its affairs, and that the voting shares of such corporation are equally divided into two independent ownerships or interests" and that the shareholders be "unable to agree on, or vote for, the election of a board of directors consisting of an uneven number. ..."24

Under this provision the law of New Jersey still may be that if the bylaws call for five directors, but there are only four in office and neither they nor the shareholders can agree upon a fifth, the case must be thrown out. ${ }^{25}$

The deadlock provision of Model Corporation Act (drafted by the Commissioners on Uniform State Laws) is similar in form to the New Jersey statute. ${ }^{26}$

Other statutes, while defining deadlock more broadly, set up varying additional requirements or standards. In New York today one can contract against the applicability of the deadlock section because it begins with the words "Unless otherwise provided in the certificate of incorporation. . .."27 Another section applicable to all proceedings for dissolution requires the decreeing court to find "that a dissolution will be beneficial to the stockholders or members and not injurious to the public."28

$\checkmark$ The latest and now leading New York case, Application of Cantelmo ${ }_{,}^{29}$ involved a corporation which had been started by the plaintiff and defendant with a capital of $\$ 3000$. At the time of the suit it was making large profits and they were drawing $\$ 25,000$ apiece with bonuses. They could not agree upon a third director. The Appellate Division refused dissolution, finding that the plaintiff had brought about the deadlock to force the defendant out and get control for himself. Speaking for the majority of the court, Justice Shientag wrote, "We see no reason why the courts should, under the circumstances here presented, lend themselves to the accomplishment of the purpose sought by the petitioner."30 The majority hung its hat on the requirement that the Court must find the dissolution "beneficial to the stockholders." "31 "[This]" said Justice Shientag, "is intended

${ }^{24}$ N.J. Stat. Ann. (1939) Title 14, § 13-1.1 (emphasis added).

${ }^{25}$ Dorf v. Hill Bus Co., 140 N.J. Eq. 444, 54 A. 2d 761 (1947); but cf. the Chancellor's statement in the same case that he has general equity power to dissolve, $54 \mathrm{~A} .2 \mathrm{~d} 761,763$.

${ }^{26}$ Model Business Corporation Act $\$ 51$, adopted in Louisiana, L. 1928, Act 250, $\$ 55$; and in Washington, Rev. Stat. Ann. (Remington, 1940) §3803-50.

${ }^{27}$ N.Y. Gen. Corp. Law (McKinney, 1943) § 103, amended by N.Y.L. (1944) c. 276, § 2.

28 N.Y. Gen. Corp. Law (McKinney, 1943) § 117.

2988 N.Y.S. 2d 604 (1st Dep't, 1949), noted in 50 Col. L. Rev. 100 (1950).

${ }^{30}$ Ibid., at 606 .

${ }^{31}$ N.Y. Gen. Corp. Law (McKinney, 1943) § 117. 
to mean something, and it applies with peculiar force to the situation here involved." ${ }^{32}$ Justice Cohn dissented, pointing out, among other things, that in the course of negotiations preliminary to the suit, counsel for the defendant had threatened an application for dissolution under the deadlock statute; that if the business were sold either party would have an equal opportunity to buy it. ${ }^{33}$ Since this decision the New York Courts require the plaintiff in a deadlock case first to establish his own good faith before his petition will be considered..$^{34}$ Shades of requiring that plaintiff plead and prove freedom from contributory negligence!

Indiana, Missouri and Pennsylvania require a showing that "irreparable injury to the corporation is being suffered or is threatened by reason of the deadlock." From 1933 to 1951, the Illinois provision was the same. ${ }^{35}$ The only reported Illinois case decided under this provision still indicates strict construction. The plaintiff, $50 \%$ shareholder, sued the other $50 \%$ shareholder for forming another corporation to exploit trade-marks owned by the first corporation. The defendant counterclaimed for dissolution, alleging deadlock. The court thought that the defendant had tried to wrest control from the plaintiff; that the acts of the plaintiff were not "oppressive or fraudulent" 36 and that the evidence was insufficient to establish that "irreparable injury would result to the corporation from the deadlock." It dismissed the counterclaim. ${ }^{37}$

Outside of the important commercial states of New York and Illinois the courts have found less difficulty. Those of Pennsylvania and Missouri have construed the phrase "irreparable injury to the corporation" as encompassing not only the "legal personality" of the enterprise, but the real interests of its owners. Said the Missouri Supreme Court in a recent case in which two brothers were unable to agree upon their policies and operations:

We think [dissolution] is a better remedy than for courts to undertake to run the affairs of corporations over long indefinite periods. ... It would certainly be most unfair to do this ... wholly at the expense of defendant. ${ }^{38}$

${ }^{32}$ Application of Cantelmo, 88 N.Y.S. 2d 604, 606 (1st Dep't, 1949).

${ }^{33}$ Ibid., at 607.

${ }^{34}$ Petition of Adler, 98 N.Y.S. 2d 383 (1st Dep't, 1950).

${ }^{35}$ Ind. Stat. Ann. (Burns, 1933) §25-242(6); Mo. L. (1943) §88; Pa. Bus. Corp. Law $\S 1107$; Ill. Bus. Corp. Act (1951) §86(a)(1).

${ }^{36}$ IIl. Bus. Corp. Act (1951) $\S 86(\mathrm{a})(2)$.

${ }^{37}$ Lush'us Distributors v. Ft. Dearborn Lith. Co., 330 Ill. App. 216, 70 N.E. $2 d 737$ (1946).

${ }^{38}$ Handlan v. Handlan, 360 Mo. 1150, 1166, 232 S.W. 2d 944, 951 (1950); see also Bowman v. Gum, Inc., 321 Pa. 516, 184 Atl. 258 (1936); Garrett v. George K. Garrett Co., 39 D. \& C. (Pa.) 179 (1940). 
Obviously such thinking is a clear reflection of the classic (and proper) reluctance of the courts to "put themselves in business." The result is still easier to reach under statutes such as those of California and Minnesota, which merely require the finding

that there is internal dissension and that two or more factions of the shareholders of the corporation are so deadlocked that its business cannot longer be conducted with advantage to its shareholders. ${ }^{39}$

Thus the Minnesota Court in its most recent opinion decreed dissolution because

[i]t clearly appears from the respective petitions that the bitterness between the two factions has reached a point where, regardless of the fact that a suggestion by one of them may be for the benefit of the corporation, the other will vote against it. ${ }^{40}$

It has been suggested that the courts' reluctance to dissolve varies in inverse ratio to the prosperity of the enterprise; that where the faction which happens to be in office at the date of the resignation, death or other incident which caused the deadlock is continuing to manage the company successfully, it is necessary in addition to prove some measure of exploitation of the minority.11 In the writer's view the cases do not bear this out. The New Jersey courts, for instance, have recently dissolved two substantially sized and prosperous deadlocked corporations, holding that (given an even-numbered board) the very fact of deadlock creates corporate "paralysis" and requires dissolution. In one of these cases, the dispute was between the preferred and common stockholders, each class represented by two directors, over the wisdom of paying preferred dividendsfor which earnings were clearly sufficient. The court drove off the sacred cow: [W] here as here, corporate function can no longer be had due to irreconcilable differences between two independent classes of stockholders of equal voting power, the corporation is subject to dissolution in the interest of the public and the shareholders who may suffer injury. . . A Corporation does not have an absolute right to existence in perpetuity ... under the management of one who happened to be serving in that capacity when the deadlock occurred. ${ }^{42}$

The second case, involving the affairs of Jersey City's leading newspaper, the Jersey Journal, ended, after decree, with a buy-out of one fac-

${ }^{39}$ Minn. Stat. (1949) $\$ 301.49(4)$; Calif. Corp. Code (Deering, 1948) $\S 4651$ (d). The California statute has one unique feature: Where the stockholders are unable to agree upon an odd director, the court can appoint one. Ibid., at $\$ 4655$.

${ }^{10}$ In re Hedberg-Friedheim \& Co., 233 Minn. 534, 538, 47 N.W. 2d 424, 427 (1951).

${ }^{41}$ See, e.g., Deadlock as Ground for Dissolution under New York Corporation Law, 50 Col. L. Rev. 100 (1950).

42 Petition of Collins-Doan Co., 3 N.J. 382, 389, 70 A. 2d 159, 163 (1949), annotated in 13 A.L.R. 2d 1250 (1949) (emphasis added). Accord: R.K.O. Theatres v. Trenton-New Bruns. Theatres Co., 8 N.J. Super. 404, 72 A. 2d 14 (1950). 
tion by the other only a few months ago. ${ }^{43}$ In contrast, the New York court's resort to a sort of "clean-hands" doctrine in the Cantelmo case against a background of prosperity lends color to the argument that prosperity of the enterprise under its holdover management is a factor, but most of the other cases which appear in point involved marital difficulties. $^{44}$ v

A 1951 amendment to the Illinois Business Corporation Act lays down the clearest pragmatic statutory standard for deadlock or stalemate as a ground for dissolution. Section 86(a)(2) now provides

(2) That the shareholders are deadlocked in voting power, and have failed, for a period which includes at least two consecutive annual meeting dates, to elect successors to directors whose term has expired or would have expired upon the election of their successors. ${ }^{45}$

The statute is, of course, too new yet to have met construction. It is to be hoped that the courts construing it will avoid the "clean-hands" pitfall, and, if they see a choice between the reasoning of the New York and the New Jersey courts on that point, follow the latter. ${ }^{46}$

As will be obvious from the foregoing discussion, there will be difficulty in applying many of the deadlock statutes to the stalemate case. Many are drawn for deadlock only, referring to "equal" division into "two" factions, ${ }^{47}$ or requiring that the holders of fifty percent of the shares file the petition. ${ }^{48}$ Others would be easily applied. ${ }^{49} \mathrm{~A}$ third group would be applicable only if the interest petitioning for dissolution were large enough, though less than fifty percent, to meet the statutory minimum. ${ }^{50}$ In the latter group are the statutes of the Carolinas and of West Virginia. They are worth special mention because they permit a petition based, not upon deadlock or stalemate as such, but upon a ground which will often exist in

43 In re Evening Journal Ass'n, 1 N.J. 437, 64 A. 2d 80 (1949), 15 N.J. Sup. 58, 83 A. 2d 38 (1951); the fact of the sale was reported in 58 Time, No. 22, at 60 (Nov. 26, 1951).

44 E.g., Valerie Bland v. Lee C. Bland Corp., 16 Conn. Supp. 268 (Super. Ct., 1949); Application of George W. Anderson, Inc. 104 N.X.S. 2d 184 (S. Ct., 1951).

45 III. Bus. Corp. Act (1951) §86(a)(2).

${ }^{46}$ Lush'us Distributors, Inc. v. Ft. Dearborn Iith. Co., 332 Ill. App. 216, 70 N.E. 2d 737 (1946), points up the danger. The New Jersey court in In Re Evening Journal Association, specifically rejected the rationale of the Cantelmo case. For a suggestion as to how a case of clear bad faith on plaintiff's part may perhaps be intelligently dealt with, see infra p. 788 et seq.

${ }^{47}$ E.g., New Jersey, note 24 supra.

${ }^{8}$ E.g., Michigan, New York, Ohio, note 14 supra.

${ }^{49}$ E.g., Ill., Minn., note 15 supra.

${ }^{80}$ Massachusetts permits a petition by the holders of $40 \%$ of the shares, Ann. Laws Mass. (1948) c. 155, § 50; California by one-third. Calif. Corp. Code (Deering, 1948) §4650(b). 
such a case-namely failure to pay dividends for a specified period. The Carolinas ${ }^{51}$ permit a petition by the holders of one-fifth or more of the shares alleging (a) that earnings have been insufficient to pay dividends on the paid-up stock for the preceding three years; or (b) that no dividends have been paid at all for the preceding five or six years. Where no dividends have been paid on common stock for ten years or more, the holders of $10 \%$ of the outstanding paid-up common may petition. However; there are no reported deadlock or stalemate cases under these statutes, and the decisions emphasize the discretionary power of the courts to deny relief in times of stress, either in the general economy or in the particular company's affairs. ${ }^{52}$ West Virginia permits the holders of $25 \%$ or more to file, alleging failure to pay dividends for two years, whereupon the court may "if sufficient cause be shown" dissolve the corporation..$^{53}$ In a series of cases which do not appear to have involved genuine deadlock or stalemate the courts equated "sufficient cause" to "possible insolvency due to mismanagement and diverting of funds of the company." fronted in 1950 with a clear deadlock case, the West Virginia Supreme Court failed to see the difference. It first dismissed the bill for lack of specific allegations of mismanagement; $;^{55}$ and sustained it only after it was amended to allege misappropriation of $\$ 2500$ of corporate funds, the increase of defendant's salary at meetings of which plaintiff had received no notice, and the like..$^{56}$ It seems to the writer that the first decision was wrong, particularly in the light of the revision of the statute in 1929 to include a provision permitting the defendants to avoid dissolution by purchasing the plaintiff's stock at an appraised value set by the court. ${ }^{57}$

So much for the statutory gamut. Apart from statute there has been progress also. Thus several courts have held that they have general equity power to dissolve a corporation. As early as 1908 the courts of Washington had held that lacking general equity power to dissolve, they had such power to liquidate or wind up the corporate business and thus reach the

s1 Gen. Stat. N.C. (1950) §55-125; S.C. Code (1942) § 7725.

32 Kistler v. Cotton Mills Co., 205 N.C. 809, 172 S.E. 373 (1934); Towles v. S.C. Produce Ass'n, 187 S.C. 290, 197 S.E. 305 (1938).

63 W.Va. Code Ann. (1949) c. 31, § 3093.

64 Hirsch v. Independent Steel Co. of America, 196 Fed. 104 (S.D.W.Va., 1911). Accord: Stevens v. Empire Casualty Co., 180 Fed. 283 (N.D.W.Va., 1910); Robinson v. Company, 110 W.Va. 143, 157 S.E. 85 (1931); cf. Williams v. Notion Co., 82 W.Va. 549, 96 S.E. 929 (1918) which clearly involved "corporate paralysis" if not deadlock, and sustained the bill.

\footnotetext{
ss Hall v. McLuckey, Inc., 60 S.E. 2d 280 (W. Va., 1950).

s6 Hall v. McLuckey, Inc., 65 S.E. 2 d 494 (W. Va., 1951).

${ }^{67}$ California has a similar provision, Corp. Code (Deering, 1948) $\$ 4658-59$.
} 
same result..$^{58}$ The reasoning is spelled out in a leading Kansas case ${ }^{59}$ and carried to its logical conclusion by the Supreme Court of Alabama. ${ }^{60}$

In other states, courts meeting the question for the first time have decided it in favor of an inherent or general equity power to dissolve, and a few have overruled earlier decisions to the contrary. ${ }^{61}$ Some courts have reached such decisions where there was no statute. ${ }^{62}$ Others have reached it by holding the statutory remedy to be nonexclusive. Interestingly enough, two leading cases in the latter category afforded the preferred stockholders of public issue corporations relief against the refusal of directorates controlled by common shareholders to pay out preferred dividends. ${ }^{63}$

The fact that in New York and in Michigan directors alone can file for dissolution without shareholder approval has led the courts of those states to require the directors so to file in cases where the facts showed both recurring losses and abuse of managerial prerogatives. Thus where, despite a long record of losses, the principal officer and member of the majority group received a substantial and patently unjustified increase in salary, a New York court, at the petition of a minority stockholder, ordered the directors to apply for dissolution, observing that "bad faith and fraud in refraining from dissolving a corporation may be shown to be as much a breach of duty, as bad faith and fraud in seeking wrongfully to dissolve [it]." ${ }^{\prime 64}$ Michigan cases use similar language. ${ }^{65}$

${ }^{58}$ State ex rel. Conlon v. Oudin \& Bergman Fire Clay Mining \& Mfg. Co., 48 Wash. 196, 93 Pac. 219 (1908).

59 Bowen v. Bowen-Romer Flour Mills Corp., 114 Kans. 95, 217 Pac. 301 (1923).

${ }^{60}$ Cowin v. Salmon, 248 Ala. 580, 28 So. $2 \mathrm{~d} 633$ (1947). This also seems to be the law of Delaware, a relatively unimportant state, perhaps, in a close corporation context; see Lichens Co. v. Standard Commercial Tobacco Co., 28 Del. Ch. 220, 40 A. 2 d 447 (1944)..

${ }^{61}$ Flemming v. Heffner \& Flemming, 263 Mich. 561, 248 N.W. 900 (1933); Guaranty Laundry Co. v. Pulliam, 200 Okla. 185, 191 P. 2d 975 (1948); Hammond v. Hammond, 216 S.W. 2 d 630 (Tex. Civ. App. 1949). See also Dorf v. Hill Bus Co., 140 N.J. Eq. 444, 54 A. 2d 761 (1947); and Corporations-Dissolution at Instance of Minority Stockholder, 28 N.C. L. Rev. 313 (1950).

62 Guaranty Laundry Co. v. Pulliam, 200 Okla. 185, 191 P. 2d 975 (1948).

${ }^{63}$ In re Mansfield Ry. Light and Power Co., 3 Ohio App. 253 (1914); Tower-Hill Connellsville Coke Co. v. Piedmont Coal Co., 64 F. 2 d 817 (C.A. 4th, 1933). The Mansfield case is often cited for the proposition that where there is internal dissension the "public interest" might require dissolution. It is not precisely authority for that proposition. The corporation was a public utility, a traction company, and the court, interested in rescuing the local preferred stockholders from the toils of holding company control, expressed concern that the dissensions might interfere with "the reasonable discharge of [the corporation's] duties to the public."

64 Kroger v. Jaburg, 231 App. Div. 641, 248 N.Y. Supp. 387, 393 (1st Dep't, 1931); followed in Lennan v. Blakeley, 72 N.Y.S. 2d 901 (Sup. Ct. 1947).

${ }^{65}$ Holden v. Lashley-Cox Land Co., 316 Mich. 478, 25 N.W. 2d 590 (1947). "[T]he ultimate object of every trading corporation is the pecuniary gain of its stockholders ... it is 
What, then, should be the law? The writer can only express a personal view一with some judicial support-that deadlock or stalemate in a close corporation is as completely socially undesirable as in partnership or in a marriage, and that the corporate contract is not a holy sacrament. The remedy in the partnership case is beautifully simple and over the years courts of equity appear to have administered it satisfactorily. The Uniform Partnership Act draws a distinction between dissolution (the technical termination) and winding-up or liquidation of the partnership.$^{66}$ In the case of a fixed term partnership dissolution is automatic at the expiration of the term, and winding-up ensues unless the partners, all or one or more of them, decide to carry on. The interesting analogy lies in the fact that it is possible for any general partner, by his express will, to bring about a dissolution at any time regardless of the expiration of the term. The statute gives a list of causes which will justify an order of dissolution. For example:

(c) A partner has been guilty of such conduct as terids to affect prejudicially the carrying on of the business,

(d) A partner wilfully or persistently commits a breach of the partnership agreement, or otherwise so conducts himself in matters relating to the partnership business that it is not reasonably practicable to carry on the business in partnership with him,

(e) The business of the partnership can only be carried on at a loss,

(f) Other circumstances render a dissolution equitable. ${ }^{67}$

But whether or not any of the statutory grounds exist, a general partner may bring about dissolution. His only risk is that it will be considered wrongful and that, as a result, he will be penalized by losing his interest in the name and goodwill of the business to the other partners and being liable to them for any damages that they may suffer by reason of his action. $^{68}$

The point is that the dissolution takes place willy-nilly. Liquidation may or may not follow. If the dissolution is wrongful, the remaining partners have a choice. They may pay out the value of the dissolving partner's interest less damages and his share of the value of intangibles, or post bond for their indebtedness to him and continue without him for the balance of

for this purpose and no other that the capital has been advanced; and if circumstances have rendered it impossible to continue to carry out the purpose for which it was formed with profit to its stockholders, it is the duty of its managing agents to wind up its affairs." Miner v. Belle Isle Ice Co., 93 Mich. 97, 113, 53N.W. 218, 223(1892); cf. Tower-Hill Conneilsville Coke Co. v. Piedmont Coal Co., 64 F. 2d 817 (C.A. 4th, 1933).

${ }^{65}$ Uniform Partnership Act $\$ 29$.

67 Uniform Partnership Act $\S 32$.

${ }^{68}$ Uniform Partnership Act $\S 38$. 
the term. So far as the reported cases indicate the practice, the remaining partners do not usually avail themselves of the alternative of posting bond, and where they do the liability for damages for loss of profits is largely academic. It may be necessary to replace the services of the dissolving partner but unless that should involve an outlay greater than his share of the profits would have been had he continued, we probably have damnum absque injuria.

Once we assume the social desirability of requiring that the intimate relationships between the participants in a deadlocked or stalemated close corporation be cut off, the partnership analogy is obviously apt. Before there was a Minnesota deadlock statute, the Supreme Court of that State wrote:

[W] find no real disagreement in the adjudications ... in actions against mismanaged co-partnerships ... if the rule be sound as applied to co-partnerships, the manner and form of the organization of corporation would seem not a sufficient reason for denying similar relief at the suit of stockholders thereof. ${ }^{99}$

Statutory implementation should not be difficult. There are these questions: (1) Under what circumstances should petition be permitted; (2) Who may petition; and (3) How adequate and flexible would be the remedy?

As to the first question the writer would suggest either the present California-Minnesota definition, ${ }^{70}$ or the 1951 IIlinois amendment. ${ }^{71}$ The latter has the virtue of requiring a sort of "cooling-off period,"72 but in some cases two years might be too long. ${ }^{73} \mathrm{~A}$ combination of the two criteria might thus be indicated, the two-year inability to elect a board creating a conclusive presumption in favor of the petition.

As to the second item, there seems no reason why the petition should not be filed by the holder of even a single share. Granted actual deadlock or stalemate all interests, however small, are placed in jeopardy. Illinois and several other jurisdictions permit this under their present statutes. ${ }^{74}$

${ }^{69}$ Green v. National Advertising \& Amusement Co., 137 Minn. 65, 70, 162 N.W. 1056, 1058 (1917).

${ }^{70}$ Quoted, p. 785 supra.

${ }^{7}$ See p. 786 supra.

${ }^{72} \mathrm{Cf}$. the provision of the National Labor Relations Act for a statutory 90-day injunction against strikes where public health and safety may be jeopardized, Labor-Management Relations Act of 1947 at $\$ \S 208-210,61$ Stat. 155-56 (1947), 29 U.S.C.A. $\$ \$ 178-80$ (Supp., 1951).

\footnotetext{
${ }^{73}$ In several recent cases, the courts have held the parties in terrorem decreeing that failing agreement within a specified period, dissolution would be ordered. See, e.g., R.K.O. Theatres v. Trenton-New Bruns. Theatres Co., 8 N.J. Super. 404, 72 A. 2 d 914 (1950).
}

${ }^{74}$ See note 15 supra. 
As to flexibility of remedy, the courts have always been conscious of the necessity for protecting minority interests, and even majorities where forced sales or similar procedures are involved. The Supreme Court of Kentucky after deciding that

to leave these warring stockholders as they were prior to the time of the appointment of the receiver by the Circuit Court would be but to insure the wrecking of the property

\section{directed the lower court to}

order the sale on such terms as to time as to enable either party to purchase it if they desire and ... . insure such an active competition between the factions, and perhaps others, for the property, as will insure that there will be no sacrifice of it at the sale. ${ }^{75}$

In the writer's view the courts should have the power, as they do in California and in West Virginia ${ }^{76}$ to preserve the going enterprise and solve the problem by permitting acquisition of the plaintiff's stock by the defendants at an appraised value. To make the partnership analogy substantially complete, the courts should be empowered, in fixing such a value, to consider plaintiff's good faith, i.e., his responsibility for the creation and continuance of the deadlock or stalemate, the degree to which, even though responsible, his conduct may have been justified, and also to fix terms of payment.

All this, of course, is but interesting speculation. In the meantime, there appear to be two possible remedies, the first of limited applicability because it requires anticipation, the second possibly more widely useful. It is clear today that there is no legal objection to the agreement between $\mathrm{A}$, $\mathrm{B}$, and $\mathrm{C}$, each to vote his shareholdings for the election of the others as directors for a stated period or for so long as they all remain shareholders. When clients urge upon their counsel that the close corporation they are organizing should be so set up that it cannot function without their unanimous consent will they not perhaps agree-as partners often do-that if for a stated time their disagreement causes corporate paralysis, e.g., inability of the board to act-all will vote their shares for dissolution? During the three-year period when the New York statute contained a ten year limitation on the effectiveness of a charter requirement of unanimity or qualified majority for stockholders' or directors' action, this device was

${ }^{75}$ Graham v. McAdoo, 135 Ky. 677, 684, 123 S.W. 260, 262 (1909). But Kentucky seems to have slipped backward into the strict construction school. Reid Drug Co. v. Salyer, $268 \mathrm{Ky}$. 522 , 105 S.W. $2 \mathrm{~d} 625$ (1937). For another illustration of flexibility of remedy intelligently employed, see Handlan v. Handlan, 360 Mo. 1150, 232 S.W. 2d 944 (1950).

${ }^{76}$ See notes 53 and 57 supra. 
frequently resorted to to cover the contingency of nonrenewal. The writer has found no case that questions its validity and there are two cases, one in New York and one in Massachusetts, which not only do not question the enforcibility of the agreement but indicate the courts' willingness to specifically enforce it. ${ }^{77}$

The broader suggestion may seem at first blush more radical, but I submit actually is nothing more than the old common-law process of fitting the facts into a familiar category. Why should not a court of equity determine that the participants in a deadlocked or stalemated close corporation are joint venturers as between themselves?

The law as to joint venture is not too clear in many aspects. But it is clear that the concept is not rigid; that it does not require an explicit agreement applying the label "joint venture" to the activity or series of activities in question; and that the closest analogy is to a partnership at will. ${ }^{78}$ From that analogy flows the power of the Chancellor to dissolve and liquidate as in a partnership. ${ }^{79}$ That power could be exercised in any manner calculated to produce a fair result, e.g. by appraising petitioner's stockholdings for purchase by the defendants; ${ }^{80}$ or by directing the parties to vote their shares for dissolution of their creature, the corporate entity. ${ }^{81}$ Such a decision would not be the first to grant to the parties in one of their capacities relief denied to them by precedent in another. ${ }^{82}$

77 In re Block's Will, 186 Misc. 945, 60 N.Y.S. 2d 639 (Surr. Ct., 1946); Leventhal v. Atlantic Finance Co., 316 Mass. 194, 55 N.E. 2d 20 (1944). Flanagan v. Flanagan, 273 App. Div. 918, 79 N.Y.S. 2d 682 (2d Dept., 1948), aff'd, 298 N.Y. 787, 83 N.E. 2d 473 (1948), is cited by Hornstein, Stockholders' Agreements in the Closely Feld Corporation, 59 Yale L.]. 1040 (1950), for the proposition that an agreement to dissolve in various contingencies is invalid "because it attempted to make a "partnership of the corporation." "The writer does not think this a correct interpretation because the agreement was not phrased in terms of the stockholders voting for dissolution but in terms of requiring a distribution of corporate property if and when the event occurred. In view of the two cases cited, the writer believes a better drawn agreement could have produced the opposite result.

${ }^{78}$ See generally, Nichols, Joint Ventures, 36 Va. L. Rev. 425 (1950).

${ }^{79}$ See, e.g., Null v. Parsons, 145 Ill. App. 436 (1908).

${ }^{80} \mathrm{Cf}$. the California statute, note 57 supra, and that of West Virginia, note 53 supra.

81 Cf. Kroger v. Jaburg, 231 App. Div. 641, 248 N.Y. Supp. 387 (1st Dep't, 1931) and Holden v. Lashley-Cox Land Co., 316 Mich. 478, 25 N.W. 2d 590 (1947).

${ }^{82}$ Null v. Parsons, 145 Ill. App. 436 (1908), distinguished the remedy of partition which the court seemed to think was not available, but in effect reached the same result. Cf. the recent (unreported) decision of the Superior Court of Cook County, Illinois in Leibrandt v. Finder, No. 49 S 18333 (June 28, 1951), finding, and directing dissolution of a joint venture as between the beneficiaries of an Illinois land trust to whom, as such, partition could not have been granted. 
Once it be granted that the participants in a close corporation should be permitted, as between themselves, to impose personal vetoes on the powers usually vested by our corporate statutes in majorities, it seems clear to the writer that a simple and flexible remedy for deadlock or stalemate must be provided, and that the untouchability of the sacred cow must not be permitted to impede its exercise. Too precise definition, too onerous requirements as to who may seek relief, and too much rigidity of available remedy will do social harm. What we need is faith in the sensitivity of the Chancellor's foot, and to permit him, with due dignity, and in a proper case, to apply the boot to the sacred cow of corporate existence. 